\title{
Ultra-processed foods in childhood: a system of violation of rights and food and
}

\section{nutrition insecurity}

\author{
Ultraprocessados na infância: um sistema de violação de direitos e insegurança alimentar e \\ nutricional
}

\begin{abstract}
Alimentos ultraprocesados en la infancia: un sistema de vulneración de derechos e inseguridad alimentaria y nutricional
\end{abstract}

Received: 10/09/2021 | Reviewed: 10/17/2021 | Accept: 10/23/2021| Published: 10/25/2021

Beatriz Gouveia Moura
ORCID: https://orcid.org/0000-0002-5931-1570
Federal University of Sergipe, Brazil
E-mail: beatrizgouvs @ gmail.com
Jamille Caroso de Andrade
ORCID: https://orcid.org/0000-0002-5261-9812
Federal University of Sergipe, Brazil
E-mail: jamillecaroso@ gmail.com
Adriana Correia dos Santos
ORCID: https://orcid.org/0000-0002-8603-8872
Federal University of Sergipe, Brazil
E-mail: adriana_soriso@ @otmail.com
Rodrigo do Nascimento Lopes
ORCID: https://orcid.org/0000-0002-2979-3441
Federal University of Sergipe, Brazil
E-mail: playerodrigoall@ gmail.com
Maria Emília Lisboa Pacheco
ORCID: https://orcid.org/0000-0003-3586-117X
Federation of Organs for Social and Educational Assistance, Brasil
E-mail: memilia@ fase.org.br
Silvia Maria Voci
ORCID: https://orcid.org/0000-0002-7087-7233
Federal University of Sergipe, Brasil
E-mail: smvoci@uol.com.com

\begin{abstract}
Discussions on the health consequences of the consumption of ultra-processed foods (UPFs) are wide-ranging, but little has been addressed under systemic aspects, human rights, sovereignty and food and nutrition security, and socioenvironmental sustainability. For this reason, the aim of this article was to analyze the systemic implications of children's access to UPFs. Secondary data from a cross-sectional survey conducted with pre-school students of two private schools in a capital city in the Northeastern region of Brazil were analyzed through the analysis of lunch boxes for three consecutive days. The most frequent UPFs had information about the manufacturing location, ingredients, and brand collected from their labels and subsequently studied. We noticed that most of the products were manufactured in other states, being transported for long distances, had little ingredient diversity, and belonged to subbrands that conglomerate into "big players". In this sense, we conclude that children are having their right to food violated and that access to UPFs by this public supports a hegemonic and unsustainable food system from a socioenvironmental point of view that contributes to food and nutrition insecurity.
\end{abstract}

Keywords: Industrialized foods; Food security; Child nutrition.

\section{Resumo}

Discussões sobre as consequências do consumo de alimentos ultraprocessados (AUP) para a saúde são amplas, mas pouco tem se abordado sob aspectos sistêmicos, direitos humanos, soberania e segurança alimentar e nutricional e sustentabilidade socioambiental. Por este motivo, o presente artigo teve como objetivo analisar as implicações sistêmicas do acesso aos AUP pelas crianças. Foram analisados dados secundários de uma pesquisa transversal realizada com escolares da educação infantil de duas escolas particulares de uma capital do Nordeste brasileiro, levantados por meio de registro de três dias não consecutivos dos alimentos das lancheiras. Os AUP mais frequentes tiveram informações sobre local da fabricação, ingredientes e marca coletadas de seus rótulos e estudados. Pudemos observar que a maioria dos produtos foi fabricada em outros estados, percorrendo longas distâncias, apresentavam 
pouca diversidade nos ingredientes utilizados e pertenciam a submarcas que se conglomeram em seletos grandes nomes. Neste sentido, concluímos que as crianças estão tendo seu direito à alimentação violado e que o acesso aos AUP por este público sustenta um sistema alimentar hegemônico e insustentável do ponto de vista socioambiental que contribui para a insegurança alimentar e nutricional.

Palavras-chave: Alimentos industrializados; Segurança alimentar; Nutrição da criança.

\section{Resumen}

Las discusiones sobre las consecuencias para la salud del consumo de alimentos ultraprocesados (AUP) son extensas, pero poco se ha abordado en términos de aspectos sistémicos, derechos humanos, soberanía y seguridad alimentaria y nutricional y sostenibilidad socioambiental. Por este motivo, este artículo tuvo como objetivo analizar las implicaciones sistémicas del acceso a la PUA por parte de los niños. Se analizaron datos secundarios de una encuesta transversal realizada con preescolares de dos colegios privados en una capital del Nordeste de Brasil, recolectados a través de un registro de tres días no consecutivos de comida en loncheras. Las AUP más frecuentes tenían información sobre el lugar de fabricación, ingredientes y marca recogidos de sus etiquetas y estudiados. Pudimos observar que la mayoría de los productos se fabricaban en otros estados, viajaban largas distancias, tenían poca diversidad en los ingredientes utilizados y pertenecían a sub-marcas que se agrupaban en grandes nombres selectos. En este sentido, concluimos que se está violando el derecho a la alimentación de los niños y niñas y que el acceso a la AUP por parte de este público apoya un sistema alimentario hegemónico e insostenible desde un punto de vista socioambiental que contribuye a la inseguridad alimentaria y nutricional.

Palabras clave: Alimentos industrializados; Seguridad alimentaria; Nutrición del niño.

\section{Introduction}

Ultra-processed foods (UPFs) are highly convenient for consumption, hyper-palatable, and nutritionally unbalanced and are part of a food production and consumption chain, inserted in the agri-food system (C A Monteiro et al., 2016). Its consumption has implications on the health of individuals and ecosystems, their culture, and, consequently, the realization of rights such as adequate food and food sovereignty.

Understanding that food goes beyond a minimum calorie package or the consumption of fortified foods with nutritional appeals involves discussing the concept of food sovereignty and the dimensions of Food and Nutrition Security (FNS), important premises for the realization of the Human Right to Adequate Food and Nutrition (HRAFN).

FNS refers to the right every citizen has to be safe in relation to sufficiency (protection against hunger and malnutrition), quality (prevention of diseases associated with food), and adequacy (preservation of food culture) of food and nutrition (Maluf \& Reis, 2013). Since 1996, Via Campesina has affirmed food sovereignty as a context in which food - unlike the capitalist system and what was initially brought in by the Food and Agriculture Organization (FAO) - cannot be treated as a commodity and should be considered as everyone's right, a social asset (Coca, 2016). UPFs, in general, are transported over long distances and their ingredients arise from different places in the world, with a direct dependence on the foreign market and a continuous state of food insecurity, accentuated by the artificialization of their composition, which can also promote nutrition insecurity.

There is an ongoing discussion as to if food systems are programmed to serve children, they will work for all stages of life (Unicef, 2019). It is understood that there is an important scientific gap regarding the analysis of what children consume and what this would imply not only for their health, but for the relationships with important aspects involved in the realization of the HRAFN, such as the environment, culture, social and work relations, and everything that may be interconnected in this intricate hegemonic food system in which we are immersed.

For this reason, the present study intended to discuss the systemic implications of access to UPFs by children in guaranteeing FNS, food sovereignty, and, consequently, in the realization of the HRAFN. 


\section{Methodology}

\subsection{Study design and population}

It is a qualitative research that focuses on a deeper concern with the investigated processes and phenomena (Pinto et al., 2019). Thus, it is based on the concept of food systems in a historical and comparative view, incorporating in its understanding the various actors involved in this process and their relationships (Canesqui, 2009). Secondary data from a cross-sectional survey, carried out in private schools in the state of Sergipe, Brazil, with students enrolled in Early Childhood Education (2019), were used. The sample consisted of 355 students aged 2 to 6 years whose food information regarding the food inside their lunch boxes was available.

\subsection{Study variables and data collection}

The data were collected using a specific form for registering the food present in the students' lunch boxes, with blank fields for the type of food, quantity, and brand. The observation of three non-consecutive days of food brought by the students from home was made by a previously trained team, in the classroom, before school break, in the presence of the children and teachers.

\subsection{Data analysis and consolidation}

The records were later standardized as to the type and quantity in grams of food and tabulated in the Brasil Nutri software (Nebin, 2019). Subsequently, the 15 foods that appeared most frequently in the lunch boxes were analyzed, classified according to NOVA (Monteiro et al., 2016) and grouped into eight possible food groups. The classification and grouping were done considering the organoleptic similarities, the specifications and the ingredients of the items collected, which were also object of analysis through the observation of the labels (Brasil, 2014). The "sugar" item, which is very present in lunch boxes, was not analyzed in the present study because it is considered a culinary ingredient. However, it is worth mentioning that, in our results, we approach sugar as a frequent ingredient in the composition of the UPFs analyzed.

From the 15 most common foods, the most frequent brands were systematized. Then, a ranking was carried out in order of frequency, with the top 10 being selected to have their manufacturing sites located, via their own websites and/or food labels (verified in a local supermarket).

From their ZIP codes, it was calculated the shortest route to the region where the participating schools are located, using Google Maps®, in order to discuss access to local food. Considering the absence of a clear definition about what local food is, we chose to use the geographic limit of the state of the participating schools (Azevedo, 2015).

The main research was submitted to and approved by the Ethics Committee in Research with Human Beings of the Universidade Federal de Sergipe (UFS, Federal University of Sergipe/University Hospital), opinion number 2.701.571.

\section{Results}

Of the 3,351 food items observed in the records of the 355 students evaluated, the most frequent item was refined sugar. However, because it is a culinary ingredient that was estimated based on the criticism and standardization of recipes and preparations present in the records (such as sweetened natural juices, for example), it was disregarded from the analyzes, and the following 15 items were selected. These 15 items accumulated a frequency of 58.8\% of the total evaluated food items. We identified the highest presence of ultra-processed products (72.5\%), especially in the group of cookies and crackers (45\%). Only $10.8 \%$ of the items analyzed corresponded to unprocessed fruits (Table 1). 
Research, Society and Development, v. 10, n. 14, e64101421596, 2021

(CC BY 4.0) | ISSN 2525-3409 | DOI: http://dx.doi.org/10.33448/rsd-v10i14.21596

Table 1. List and classification of the fifteen most frequent foods in the lunch boxes of early childhood education students. Sergipe, 2020.

\begin{tabular}{|c|c|c|c|c|}
\hline $\begin{array}{l}\text { Groups - NOVA } \\
\text { classification }\end{array}$ & Food groups & Foods & $\mathrm{n}$ & $\%$ \\
\hline \multirow{9}{*}{$\begin{array}{c}\begin{array}{c}\text { Ultra-processed } \\
\text { foods }\end{array} \\
n(\text { total }): 1342 \\
\%(\text { total }): 72.5\end{array}$} & Chocolate drink & Chocolate drink & 89 & 4.5 \\
\hline & \multirow{4}{*}{$\begin{array}{l}\text { Cookies/crackers } \\
n(\text { total }): 798 \\
\%(\text { total }): 45\end{array}$} & Cookie & 272 & 13.8 \\
\hline & & Sandwich cookie & 205 & 10.4 \\
\hline & & Cracker & 170 & 8.6 \\
\hline & & Wafer & 151 & 7.7 \\
\hline & Fermented milk & Fermented milk & 77 & 3.9 \\
\hline & Corn snacks & Corn snacks & 85 & 4.3 \\
\hline & Boxed juices & Boxed juices & 259 & 13.1 \\
\hline & Yogurt & Yogurt & 123 & 6.2 \\
\hline \multirow{3}{*}{$\begin{array}{c}\text { Preparation based } \\
\text { in unprocessed } \\
\text { foods } \\
n(\text { total }): 329 \\
\%(\text { total }): 16.7\end{array}$} & \multirow[t]{3}{*}{ Fruit juices } & Passion fruit juice & 140 & 7.1 \\
\hline & & Guava juice & 102 & 5.2 \\
\hline & & Acerola juice & 87 & 4.4 \\
\hline \multirow{3}{*}{$\begin{array}{c}\text { Unprocessed foods } \\
n(\text { total }): 212 \\
\%(\text { total }): 10.8\end{array}$} & \multirow[t]{3}{*}{ Fruits } & Banana & 77 & 3.9 \\
\hline & & Apple & 77 & 3.9 \\
\hline & & Grape & 58 & 3.0 \\
\hline TOTAL & & & 1,972 & 100 \\
\hline
\end{tabular}

Source: Author's elaboration.

Regarding the ingredients (Table 2), only ultra-processed products were analyzed, with the presence of wheat flour fortified with iron and folic acid, sugar and other variations, corn, hydrogenated vegetable fat, thickeners, flavorings, preservatives, and emulsifiers being verified in most of the investigated products. 
Table 2. Most common ingredients in the analyzed food products. Sergipe, 2020.

\begin{tabular}{|c|c|}
\hline Food & Ingredients \\
\hline Cookie & $\begin{array}{l}\text { Wheat Flour Enriched with Iron and Folic Acid, Sugar, Vegetable Fat (Soy, Palm), } \\
\text { Inverted Sugar, Starch, Salt, Chemical Ferments Ammonium Bicarbonate (INS 503ii) } \\
\text { and Sodium Bicarbonate (INS 500ii), Lactic Acid Acidulant (INS 270), Soy Lecithin } \\
\text { Emulsifier (INS 322), Flavoring, Sodium Metabisulfite, and Flour Enhancer (INS 223). }\end{array}$ \\
\hline Cookie & $\begin{array}{l}\text { Wheat Flour Fortified with Iron and Folic Acid, Sugar, Vegetable Fat, Corn Cream, } \\
\text { Inverted Sugar, Starch, Salt, Soy Lecithin Stabilizer, Chemical Ferments (Ammonium } \\
\text { Bicarbonate and Sodium Bicarbonate), Lactic Acidic Acid, Flavoring, and Improver of } \\
\text { Flour Protease (INS } 1101 \text { I). }\end{array}$ \\
\hline Cracker & $\begin{array}{l}\text { Wheat Flour Enriched with Iron and Folic Acid, Vegetable Fat (Soy, Palm), Starch, } \\
\text { Malt Extract, Inverted Sugar, Salt, Biological Yeast, Chemical Yeast Sodium } \\
\text { Bicarbonate (INS 500ii), Lactic Acid Acidulant (INS 270), Protease Flour Additives } \\
\text { (INS } 1101 \text { i) and Sodium Metabisulfite (INS 223), and Xylanase Enzyme. }\end{array}$ \\
\hline $\begin{array}{l}\text { Sandwich } \\
\text { cookie }\end{array}$ & $\begin{array}{l}\text { Wheat flour enriched with iron and folic acid, sugar, vegetable oil, starch, cocoa, } \\
\text { vegetable fat, salt, rye flour, oatmeal, milk serum, whole milk powder, caramel coloring } \\
\text { IV, ammonium bicarbonate, chemical yeasts, sodium bicarbonate and monocalcium } \\
\text { phosphate, soy lecithin emulsifier, and flavoring. }\end{array}$ \\
\hline Wafer & $\begin{array}{l}\text { Wheat flour enriched with iron and folic acid, crystal sugar, hydrogenated vegetable fat, } \\
\text { cocoa powder, corn starch, salt, caramel coloring IV, soy lecithin emulsifier, chemical } \\
\text { yeast, baking soda, and flavoring. }\end{array}$ \\
\hline Yogurt & $\begin{array}{l}\text { Skimmed milk, fruit preparation (water, fructose, strawberry pulp, calcium [tricalcium } \\
\text { phosphate], concentrated lemon juice, black carrot concentrate, modified starch, vitamin } \\
\text { D [cholecalciferol], thickeners, carrageenan gum, carboxymethylcellulose and xanthan } \\
\text { gum, flavoring, and conservative potassium sorbate), sugar syrup, cream, fructose, } \\
\text { calcium chloride, milk yeast, chymosin and carboxymethylcellulose thickeners, and } \\
\text { guar gum. }\end{array}$ \\
\hline $\begin{array}{l}\text { Chocolate } \\
\text { drink }\end{array}$ & $\begin{array}{l}\text { Reconstituted milk, milk serum, water, sugar, cocoa powder, minerals (calcium, } \\
\text { magnesium, and iron), vitamins (C, B1, B2, niacin, B6, B12, pantothenic acid, biotin), } \\
\text { salt, carrageenan gum, thickeners, gum xanthan and sodium carboxymethylcellulose, } \\
\text { flavorings, and acidic citric acid. }\end{array}$ \\
\hline Corn snack & $\begin{array}{l}\text { Corn flour fortified with iron and folic acid, palm vegetable oil, requeijão-flavored } \\
\text { snacks preparation (milk serum, vegetable fat, milk protein concentrate, glucose syrup, } \\
\text { salt, maltodextrin, caseinate, butter, cheese, modified starch, flavoring, acidity regulator } \\
\text { disodium phosphate, monosodium glutamate flavor enhancer, acidulants: citric acid and } \\
\text { lactic acid, natural dyes: turmeric and annatto and emulsifiers: fatty acid mono and } \\
\text { diglycerides, and soy lecithin) and salt. }\end{array}$ \\
\hline $\begin{array}{l}\text { Fermented } \\
\text { milk }\end{array}$ & $\begin{array}{l}\text { Skimmed reconstituted milk and/or pasteurized skimmed milk, sugar syrup, inverted } \\
\text { sugar, milk yeast, zinc (zinc sulphate), pectin stabilizer, flavoring, and sucralose } \\
\text { sweetener. }\end{array}$ \\
\hline Boxed juice & $\begin{array}{l}\text { Water, grape pulp, sugar, citric acid acidulant, natural flavoring, and antioxidant } \\
\text { ascorbic acid. }\end{array}$ \\
\hline
\end{tabular}

Source: Author's elaboration.

When checking the brands of the food products found, 79 sub-brands were observed, which encompass a total of 34 brands or food companies, called parent brands. We would like to highlight that 434 items analyzed did not have the brand or sub-brand visible in the collection stage and, therefore, could not be selected. Among those that were selected, we carried out a ranking with the 10 brands that were most repeated in the lunch boxes (Table 3), which are one of the scopes of the discussion. 
Table 3. Ranking of the parent brands of the analyzed foods. Sergipe, 2020.

\begin{tabular}{lll}
\hline \multicolumn{1}{c}{ Position } & \multicolumn{1}{c}{ Parent brand } & N \\
\hline $\mathbf{1}^{\text {st }}$ & Nestlé & 213 \\
$\mathbf{2}^{\text {nd }}$ & M. Dias Branco & 154 \\
$\mathbf{3}^{\text {rd }}$ & Maratá & 139 \\
$\mathbf{4}^{\text {th }}$ & Coca-Cola & 72 \\
$\mathbf{5}^{\text {th }}$ & PepsiCo & 70 \\
$\mathbf{6}^{\text {th }}$ & Marilan & 59 \\
$\mathbf{7}^{\text {th }}$ & Mondelez & 51 \\
$\mathbf{8}^{\text {th }}$ & Betânia & 45 \\
$\mathbf{9}^{\text {th }}$ & Danone & 43 \\
$\mathbf{1 0}^{\text {th }}$ & Lactalis & 25 \\
Total - & & $\mathbf{8 7 1}$ \\
\hline
\end{tabular}

Source: Author's elaboration.

In the next step, in which we carry out the tracking of the manufacturing locations of the sub-brands that are part of the ranking of the parent brands (Table 3), we analyzed the distances (in kilometers) between these locations and Aracaju (table 4), using the shortest routes. It was noticeable the concentration of locations in countryside and small cities in several states in the Northern, Northeastern, Southeastern, and Southern regions of Brazil with routes that ranged from $69 \mathrm{~km}$ to 2,282 $\mathrm{km}$, with an average of $562.5 \mathrm{~km}$. It is important to highlight that, of the nineteen factories found, only three are in the state of Sergipe.

Table 4. Tracking of the manufacturing sites of the ranking parent brands. Sergipe, 2020.

\begin{tabular}{|c|c|c|c|c|}
\hline $\begin{array}{c}\text { Ranking } \\
\text { classification and } \\
\text { parent brand }\end{array}$ & Products & Sub-brands & $\begin{array}{c}\text { Production site in } \\
\text { Brazil } \\
\text { (city/state) }\end{array}$ & $\begin{array}{c}\text { Distance } \\
\text { to Aracaju - } \\
\text { SE }(\mathbf{K m})\end{array}$ \\
\hline \multirow{4}{*}{$1^{\text {st }}$ - Nestlé } & $\begin{array}{c}\text { Cookies and } \\
\text { sandwich cookies }\end{array}$ & $\begin{array}{l}\text { Bono, Classic, } \\
\text { Negresco, Nesfit, } \\
\text { Nestlê, Neston, } \\
\text { Passatempo }\end{array}$ & Marília - SP & 2282 \\
\hline & Yoghurts & Chamyto & Araras - SP & 2158 \\
\hline & Chocolate drinks & Nescau & Itabuna - BA & 635 \\
\hline & Yoghurts & Ninho & Guaranhuns - PE & 301 \\
\hline \multirow[t]{3}{*}{$\begin{array}{c}2^{\text {nd }}-\text { M. Dias } \\
\text { Branco }\end{array}$} & $\begin{array}{c}\text { Cookies, sandwich } \\
\text { cookies, and } \\
\text { crackers }\end{array}$ & $\begin{array}{c}\text { Adria, Amori - } \\
\text { Richester, } \\
\text { Animados Zoo - } \\
\text { Richester, } \\
\text { Chocoresco - } \\
\text { Vitarella, Escureto } \\
\text { - Richester, } \\
\text { Estrela, Fortaleza, } \\
\text { Gufs - Pilar, Pilar, } \\
\text { Piraquê, Richester }\end{array}$ & $\begin{array}{c}\text { Jaboatão dos } \\
\text { Guararapes - PE }\end{array}$ & 487 \\
\hline & Crackers & Salt Vip - Vitarella & Salvador - Bahia & 316 \\
\hline & $\begin{array}{c}\text { Cookies and } \\
\text { sandwich cookies }\end{array}$ & $\begin{array}{c}\text { Vitarella - Treloso, } \\
\text { Vitarella }\end{array}$ & Eusébio-CE & 1097 \\
\hline \multirow{2}{*}{$3^{\text {rd }}$ - Maratá } & Chocolate drinks & Maratá & Lagarto - SE & 82 \\
\hline & Boxed juices & Maratá & Estância - SE & 69 \\
\hline $4^{\text {th }}-$ Coca-Cola & Boxed juices & $\begin{array}{c}\text { Ades and Del Valle } \\
\text { Fresh }\end{array}$ & Pouso Alegre - MG & 1430 \\
\hline
\end{tabular}




\begin{tabular}{|c|c|c|c|c|}
\hline & & Kapo - Del Valle & Linhares - ES & 1244 \\
\hline \multirow[t]{2}{*}{$5^{\text {th }}-$ PepsiCo } & Corn snacks & $\begin{array}{l}\text { Doritos - Frito Lay, } \\
\text { Fandangos - Elma } \\
\text { Chips, Cheetos - } \\
\text { Elma Chips }\end{array}$ & $\begin{array}{c}\text { Cabo de Sto } \\
\text { Agostinho-PE }\end{array}$ & 474 \\
\hline & Chocolate drinks & Toddynho & $\begin{array}{c}\text { Feira de Santana - } \\
\text { BA }\end{array}$ & 311 \\
\hline $6^{\text {th }}-$ Marilan & $\begin{array}{c}\text { Cookies, sandwich } \\
\text { cookies, and } \\
\text { crackers }\end{array}$ & $\begin{array}{l}\text { Lev, Marilan, Pit } \\
\text { Stop, Teens }\end{array}$ & Marília - SP & 2287 \\
\hline \multirow[t]{2}{*}{$7^{\text {th }}-$ Mondelez } & $\begin{array}{c}\text { Cookies, sandwich } \\
\text { cookies, and } \\
\text { crackers }\end{array}$ & $\begin{array}{l}\text { Belvita, Bis Lacta, } \\
\text { Club Social }\end{array}$ & $\begin{array}{l}\text { Vitória de Santo } \\
\text { Antão-PE }\end{array}$ & 481 \\
\hline & Sandwich cookies & Oreo & $\begin{array}{c}\text { Vitória de Santo } \\
\text { Antão - PE }\end{array}$ & 490 \\
\hline \multirow[b]{2}{*}{$8^{\text {th }}-$ Betânia } & Yoghurts & Betânia & Morada Nova - CE & 945 \\
\hline & $\begin{array}{c}\text { Yoghurts and } \\
\text { chocolate drinks }\end{array}$ & Sabe & Muribeca-SE & 85 \\
\hline $9^{\text {th }}$ - Danone & Yoghurts & $\begin{array}{c}\text { Activia, Danette, } \\
\text { Danone and } \\
\text { Danoninho }\end{array}$ & Poços de Calda - MG & 2067 \\
\hline \multirow{3}{*}{$10^{\text {th }}$ - Lactalis } & \multirow{3}{*}{$\begin{array}{l}\text { Yoghurts and } \\
\text { fermented milk }\end{array}$} & Batavo & Carambeí - PR & 2618 \\
\hline & & Elegê & Bom Conselho - PE & 262 \\
\hline & & Itambé & Pará de Minas - MG & 1637 \\
\hline
\end{tabular}

Source: Author's elaboration.

\section{Discussion}

As previously discussed, the present study points to a high prevalence of UPFs in the lunch boxes analyzed, most of them with advertising aimed at children. Among these UPFs, six ingredients are frequently present, marking a repetition of raw materials treated as food commodities. We also observed the concentration of brands that are global players, with their manufacturing locations in different parts of the country, with long distances, supported by workers and territories made invisible by the expropriation of local cultures (Azevedo, 2015). These products are also supported by massive advertising focused on children, affecting generations starting in childhood. In order to facilitate the understanding of the discussion, we organized the debate on these findings in subtopics of the main topics addressed.

\subsection{Children: tomorrows food consumption}

In this topic, we intend to address the general aspects that deal with the implications of the high consumption of UPFs by children. Currently, child malnutrition must be understood in a multifactorial context that encompasses the growth of urban populations and the globalization of food systems. Unicef also points out that good nutrition at this stage of life will lead to the breaking of vicious, intergenerational cycles and will enable more developed and sustainable societies and economies (Unicef, 2019).

The question "what are our children eating?" is one of the current concerns about the effects of the prevailing lifestyle in big cities. Child consumption is also seen in a panorama marked by the sophistication of the food industry, the democratization of consumption, and a market competence in a continuous diversification of products for this public (Dutra, 2015). In addition to questioning what our children eat, we should question how child consumption and the food system surrounding it will be in the future. 
A child's food base will influence food in other stages of his or her life. Childhood is a period of great changes, from physiological to psychological changes, and it is also a time when eating habits and lifestyle are built and consolidated (Lanes et al., 2012). The family context at that moment constitutes a mediator of decisions about food so that there will be unique values, knowledge, and practices, with their own meanings (Toebe et al., 2018).

The pre-school phase is characterized by marked growth and the quality of food is an important issue for good physical and psychosocial development. In addition, regional and local foods have high nutritional value, low cost, and easy access, being a global strategy to ensure food and nutrition security for populations in all age groups (Silveira et al., 2014).

When evaluating the frequency of consumption of UPFs by children under 10 years of age, one of the studies observed an excess of this group and a causal relationship with overweight and obesity in childhood, in addition to the development of Noncommunicable Chronic Diseases (NCDs) in adulthood. The importance of the media, through children's advertising, was also highlighted as a determinant in encouraging UPFs, being part of the construction of an obesogenic environment (A. C. da S. Oliveira \& Souza, 2017). The "Child Advertising in Times of Convergence" (2016) report discusses how the media are associated with globalization and appeal viewers on the hegemonic patterns of the product consumption culture and of the media itself, generating a cycle that feeds itself (Sampaio et al., 2016).

\subsection{Ultra-processed foods: the invisibility of who produces it and how it is produced}

UPFs have a production chain that hardly shows the origin of each ingredient described on the label, as well as the organizations and companies involved in the process. In this study, such questions were also unknown. We have a complex national and international food production and distribution system, so that consumers only see the end of the process - the distribution locations - the rest being a kind of a mystery (Hernández, 2005). Invisibility is almost complete if we consider the working class that, in fact, produces food, being systematically ignored, as well as their working conditions and relationships.

In 1993, there was already a discussion of food as an individual construction, being vital to know and recognize food, so that people used to question how we can know what we are or what we will become when we do not know what we are eating15. From this, the expression Unidentified Edible Object (UEO) was coined for ultra-processed foods (Fischler, 1993).

In contrast, we have real food as defined in the Fifth National Conference on Food and Nutrition security (2015) and which, for this discussion, stands out as a guarantee of food sovereignty that brings production closer to consumption and promotes, protects, and respects human rights and socio-biodiversity (CONSEA, 2015). Ultra-processed food is a blackout for our relationships and connections with real food so that not knowing what happens behind the walls of industrial agriculture is eating in ignorance (Pollan, 2006).

Matthes and Checcucci use the example of transforming traditional and regional food into UFPs and instigate reflection on the impacts that may occur for the community, with emphasis on the weakening of the market and local producers in relation to the global (Matthes \& Checcucci, 2019). Furthermore, Esteve questions where our food comes from and how much of it is becoming more similar in several countries, so that there is more dependence on a few varieties of cultures (Esteve, 2017).

Some studies that address the conditions of workers involved in food systems, such as truck drivers and sugarcane cutters, explain their importance in the globalized market and the presence of exhaustive working hours, diseases resulting from work activities and remunerations that are incompatible with the service provided (Luz et al., 2014; T. T. Souza, 2017). The impacts of the hegemonic food system also affect the rural population, who live in a situation where they are forced to sell or lease their land to producers of transgenic corn and sugarcane or produce these products for plants and agro-industries (Jesus et al., 2020).

This situation generates a contradiction in the rural area and takes the sovereignty of farmers away, dependent on the 
interests of the multinationals that own seeds and pesticides and the large chains of industries and supermarkets (Machado et al., 2016). In addition, it is noted that food labels contain minimal information and the production process preceding their consumption is unknown, as are the men and women responsible for production and distribution. Since these products are easily aimed at children, there may be an incentive for an alienated and ignorant generation who do not know what real food is like, reproducing unsustainable consumption patterns.

\subsection{Distant foods}

It was noticed that the manufacturing sites described on the labels were mostly confined to territories far from the place of consumption. At this point, it should be noted that when adding the term "adequate" to the definition of healthy eating, socio-environmental and cultural dimensions were incorporated, contributing to sustainable agri-food systems, based on family farming and organic agriculture, favoring food sovereignty, considering the place as the main place of production and consumption (Azevedo, 2018). It can be said, therefore, that the long distances from the production sites go against the concept of adequate and healthy food, showing a violation of the HRAFN and the food sovereignty of children who presented such foods in their lunch boxes.

According to Esteve, there is an estimate of the fact that, on average, a meal travels about 5,000 kilometers from the field to the table, with a relocation of food production (Esteve, 2017). The concept of food miles was created by Tim Lang in the mid-1990s and alludes to the distance traveled by food in the production process and its environmental impacts (Azevedo, 2015). This concept is associated with the discussion about sustainability and sustainable food consumption, also associating with regional and cultural eating, in addition to a close relationship with the producer (Azevedo, 2015; Castro, 2018).

Revealing the location, based on food consumption, brings recognition to the people at the base of the production chain, enables new compositions, and also strengthens the generation of income and the local economy (Abdala, 2019). In this way, from the moment we have a type of food that is manufactured and produced so far, we lose the chance to strengthen the local population and the identity of those who produce it. In this way it is possible to realize that the concept of local food is (and must be) far beyond the geographical location. Knowing how the food was produced, the economic, the political and socio-cultural relationships that encompass it, as well as the people who are part of the entire food system that involves it, needs to be considered in its definition (Coelho et al., 2018).

In addition, the distribution is equivalent to a small part of the food production, being necessary to understand the entire path covered and how it is performed (Coelho et al., 2018). However, even if there is locally produced food, it is not always guaranteed that this production will be sustainable. In this sense, having a food product from a local brand does not indicate greater sustainability and/or promotion of social rights, including the HRAFN. As an example, we can mention the emergence of new productive forms that allow industrial decentralization, leading to the establishment of industries, which are seeking benefits, in small cities (Lovadini, 2017). In Sergipe, there was a subordination of family farming units to the capital, mainly in the cities of Lagarto, Boquim, and Salgado, famous for their orange production, being directed to agribusiness companies and owners of concentrated juice industries, a type of food that is quite common in the lunch boxes (Alexandre Luz Conceição, 2011).

The growing participation of industrial groups, including food industries, in Lagarto/SE brought about an integration of local family farming with agribusinesses, so that new crops were introduced to meet the demand of these groups. Despite Oliveira's study seeing the situation from a positive perspective, what is observed in practice is a dependence on large markets with production modifications - previously autonomous, agroecological, varied, and traditional - and attack on food sovereignty and the farmer's own right to choose what to plant and how to plant (Oliveira \& Costa, 2013)

In addition, in a context of difficulties in earning their livelihood from their land in order to survive, food producers 
become salary earners, a fact that is recurrent mainly among young people in the countryside. In this way, industries in cities in the countryside of the state of Sergipe lure family farmers who end up becoming employees of the landowners, often accepting low salaries, precarious conditions, and a function without socio-cultural significance (Conceição, 2007).

At this point, we must turn our attention to the idea of local food - or food product -, manufactured and/or produced locally, and understand that if this food was made in the territory while promoting the destruction and/or precariousness of this same place or the people who occupy it, it does not promote sustainability. In the same way, a food that, in its production process, deconstructs and weakens the countryside, being produced by workers in precarious conditions, expresses a continuous violation of rights. Thus, it is reflected on how many liters and which fuels support the consumption of UPFs by children and the need for this inquiry together with the development of educational projects for children and adolescents in order to develop food citizenship in them.

\subsection{Mother of all: the concentration of brands}

Initially, a wide range of brands were found in the investigated labels in the study, but they were mostly conglomerates, with a concentration on a few parent brands. The parent brand is the parent company, a kind of umbrella for all the company's products and services. This brand can be visible, being a reference for consumption, but it can also be unknown and give way to smaller brands, known to the consumer (Garcia et al., 2011).

In this sense, we observed the existence of sub-brands associated with a parent brand, the first of which was generally more prominent than the corporate brand. This strategy can cause the sensation of a false diversity of brands when, in fact, there is an increasingly concentrated market in specific names. To illustrate the consequences that result from this concentration, we can mention the case of Nestlé that in 2011 had around 140 brands and sectors connected in networks that encompass various types of food and beverages being produced within the group and also by controlled and outsourced companies. The brand maintains an articulation with local, regional, and national political agencies based on its interests, going together with the manipulation of the population through a discourse of social well-being (Bomtempo, 2011).

Nestlé cookies and crackers are prepared by machines controlled by a computerized system, baked for 7 to 8 minutes, produced in about 50 minutes, manually packed by women, and boxed by men. According to a report by a worker, which came up in the Bomtempo study, the workers are like machines and, in each line/conveyor, there are five workers responsible for packing 60 to 70 packages of cookies and crackers per minute (Bomtempo, 2011).

In Brazil, we have an agri-food system that starts with large agricultural and livestock multinationals - encouraging farmers to produce commodities - and ends with the sale of UPFs, which are easily found anywhere in the Brazilian territory, even in food deserts - regions where access to unprocessed or minimally processed foods is insufficient or non-existent34- it is increasingly perceived a strong existence of the political and scientific influence of these companies, through food lobbies (Azevedo, 2019; IDEC, 2020). These corporations operate globally and locally, influencing food environments and negatively impacting the HRAFN (Souza \& Carvalho, 2019). In addition, the arrival of transnational companies in underdeveloped countries are contributing to faster and more costly changes in eating habits than when they enter developed countries (Vicentini, 2015).

An OXFAM campaign addressed the fact that Nestlé, PepsiCo, Unilever, Mondelez, Coca-Cola, Mars, Danone, Associated British Foods (ABF), General Mills, and Kellogg's control the global food market and earn together 1.1 billion dollars a day (OXFAM, 2013). It is important to note that a large part of the companies included in the study are also in the ranking of the foods analyzed in this paper. Companies do not report on how they obtain their raw materials, do not have enough policies to protect local communities and do not commit to guaranteeing fair prices to producers who supply raw materials (OXFAM, 2013). 
In this way, we have an oligopolistic UPF market dominated by transnational corporations, with two companies having more than two thirds of all sales. Thus, in general, in countries whose national governments use deregulation policies and provide tax benefits for large companies, the entire ultra-processed chain is favored (OPAS \& OMS, 2017).

In this sense, companies/brands control all axes of the agri-food system and the concentration of what is consumed in a few names is a counterpoint to the ideal of democratization of what we eat. This agglomeration, dictating the rules and conditions and even the territories in which it is present, is an antonym for the concept of diversity and promotes the concentration of income and the increase of inequalities. Thus, as emphasized by Patel, the food we eat is no longer produced for us, we are produced for our food (Junior \& Borges, 2019). Therefore, when we observe the predominance of UPFs in the lunch boxes analyzed, we can see that this maxim makes sense: children are being perversely programmed to be consumers of this type of food.

\subsection{Sugarcane, wheat, corn, and the unknown ingredients}

The frequency of raw materials such as wheat, sugarcane, and oil and/or vegetable fat (which may come from soybeans or corn) and chemical ingredients, which are difficult to find in kitchens, were highlighted in the study's findings and indicate such foods as "Big Foods". The term was coined by Monteiro and Cannon on UPFs made from substances taken from whole foods - such as cheap parts or animal carcasses -, low-cost ingredients such as starches, sugars, fats, and vegetable oils, in addition to preservatives and other additions (Monteiro \& Cannon, 2012). These ingredients are often also supplied by large supplier companies, such as Cargill, Bunge, and Duas Rodas (Bomtempo, 2011).

Associated with this, Khoury et al. observed an increase in the production of foods such as soybeans, sunflowers, palm oil, wheat, rice, corn, and barley at the same time as there is a reduction in the production of regional foods such as yam, cassava, and sweet potato (Khoury et al., 2014). In Sergipe, there was a reduction in the production of traditional foods for instate consumption, with a 50\% reduction in the plantation of beans and cassava across a seven-year timespan, while increasing the plantation of corn plantation (Santana et al., 2018). It is also noteworthy that the origin of the production of these food commodities is based on monocultures that are often transgenic. Thus, there is a negative socio-environmental impact, an attack on the preservation of local habits and the biodiversity of seeds and local populations (Zimmermann, 2009). It is a system that exists from the exploitation of cheap labor and an abundance of land that does not consider the adverse effects on health and ecosystems (Porto, 2007).

Another discussion brought up by Scrinis is the idea based on nutritionism - which focuses specifically on nutrients as a way of understanding the effects of food on health - in which food companies adopt three different strategies to maintain and/or increase their sales in the markets. The first strategy consists of the reformulation of foods, in order to reduce compounds harmful to health; the second would be fortification with micronutrients to supply deficiencies; and the last is the functionalization of products to offer health benefits (Scrinis, 2015). The latter two strategies are commonly found in foods consumed by or aimed specifically at children.

In other words, UPFs are made for an apparent biological suitability and, thus, use ingredients originating from specific parts of food and generally grown in large monocultures. However, despite the strategy and a strong appeal to the benefits for children, some studies47,48 observed UPFs with unbalanced nutritional values and containing additives associated with childhood diseases (Louzada et al., 2015; Silva et al., 2019).

\subsection{The (un) sustainability of an oppressive food system}

There is a higher presence of UPFs in the people's daily lives, including students' lunch boxes, replacing other traditional and local foods. Along the food chain, there is a link that is led by the processing industry, highlighting its dominant 
strength in dictating purchase prices from suppliers and sovereignty in its connections to the consumer, covering technological changes in production and distribution, as well as influencing the expansion of markets (Paula, 2017).

In a context where advertising favors the purchase of ultra-processed products; that actively participates in the (de) construction of the population's eating habits, being the product of a political game that results in a failed regulation of companies, and facilitates their entry into the market, transferring responsibility for the consumption of UPFs to individuals does not seem promising. For this reason, an agri-food system that is based on these products becomes oppressive because there is no possibility of egalitarian choice. This can be represented either by their workers, who sometimes control of the industry in their territories, or by consumers, who buy what they have available on the shelves of large retailers.

Food and nutrition insecurity can arise in different ways and at different levels, but wouldn't it be the impossibility of knowing what you are eating a consistent indicator of insecurity? It is not possible to claim that a product promotes an individual's FNS when its own label does not say the least to recognize it as a healthy food. Furthermore, if this product has as its only address a distant location and/or transforms local territories into monocultures and precariously employs small producers in the region, changing what they plant for whatever is necessary for the industry, there is, in this situation, an attack on food sovereignty and the sovereignty of local populations.

Thus, if there is a change in the territories and even in the existing food crops, the culture and the local economy are also affected. The first, for replacing traditional foods, normalizing the consumption of foods no longer recognized by culinary traditions. The second, for having has a market that serves to feed foreign trade and that deprives communities and workers of the autonomy and power to choose what to plant, what to produce, and what to consume.

Sustainability is the search for balance, equity in access to nature, and the recognition that human beings must take advantage of natural resources, provided that this use serves and guarantees their well-being (Gudynas, 2019). From this perspective, it can be said that the consumption of UPFs does not favor well-being, as it does not respect the various authors of nature, including the lives of men and women, from the beginning of their production until the consumption.

This structure remains very well supported also by the context of dismantling public policies, by the dissolution of the instances of participation and social control (as can be seen by the extinction of the Conselho Nacional de Segurança Alimentar e Nutricional (CONSEA, National Council for Food and Nutrition Security), and fiscal austerity, contributing for the shutdown of the National FNS Policy. This context deepens inequalities and creates gaps used by companies to expand their power and influence, also contributing to the normalized spread of consumption of UPFs in childhood. Thus, there is an unsustainable and oppressive food system that directly affects the HRAFN, FNS, and the agrobiodiversity of current and future generations.

\section{Conclusion}

We conclude that the predominant existence of UPFs in the lunch boxes of schoolchildren that are so young, in the state of Sergipe, represents impacts that exceed individual health issues, reverberating throughout the food system. The implications discussed relate this consumption to a reduction in FNS, violation of rights - beyond the HRAFN - and negative consequences for the food sovereignty of the territories, also affecting the culture and food traditions of these different places. We observed that children are not only an indication of current food consumption but can estimate the quality of future consumption.

The individual is inserted in a social context, which means observing health promotion in a multidimensional way in the health-disease-care process. In this sense, the promotion of healthy eating practices involves systemic observation and action, going beyond the individual, and questioning the macro-social determinants (Fischler, 1993). The statements made in this analysis are in dialogue with the concept of FNS and justify the latent need to debate consumption from the perspective of 
food systems. In the same way, the results found reinforce the need for a regulation of advertising, especially aimed at children and their parents, and a review of tax benefits directed to the UPF industry.

Finally, there is a need for more studies that address a systemic discussion on the effects of ultra-processed products, the origin of their production and that seek to make the actors involved visible. Also associated with this is the carrying out of research at the local level from a citizen perspective and that takes into account territorial differences.

In addition, the need to defend territories and real food is also considered, with the strengthening of programs - such as the Programa Nacional de Alimentação Escolar (PNAE, National School Feeding Program) and the Programa de Aquisição de Alimentos (PAA, Food Acquisition Program), with the incentive to further studies guided by a citizen science project, with a popular and joint formation of society and even with the defense of democracy and national sovereignty, so weakened in the current scenario.

\section{Acknowledgments}

Thanks in particular to the sponsors who made this research possible. This study was partially funded by the Foundation for Support to Research and Technological Innovation of the State of Sergipe (Fapitec / SE) - Brazil, the Coordination for the Improvement of Higher Education Personnel - Brazil (CAPES - Financial Code 001) and the National Council of Scientific and Technological Development (CNPq).

\section{References}

Abdala, M. (2019). Práticas sustentáveis temperadas por memórias e experiências. Revista Ingesta, 1(1), 159-171. https://doi.org/10.11606/ISSN.25963147.V1I1P159-171

Azevedo, E. de. (2015). O ativismo alimentar na perspectiva do locavorismo. Ambiente \& Sociedade, 18(3), 81-98. https://doi.org/10.1590/18094422ASOC740V1832015

Azevedo, E. de. (2018). Alimentação Saudável para que/m? Geografares, 25, 105-112.

Azevedo, E. (2019). Lobbies alimentares. Revista Ingesta, 1(1), 53-67. https://doi.org/10.11606/issn.2596-3147.v1i1p53-67

Bomtempo, D. C. (2011). Dinâmica territorial, atividade industrial e cidade média: as interações espaciais e os circuitos espaciais da produção das indústrias alimentícias de consumo final instaladas na cidade de Marília - SP [Universidade Estadual Paulista (UNESP)]. In Aleph. https://repositorio.unesp.br/handle/11449/105059

Brasil, M. da S. (2014). Guia Alimentar para a População Brasileira.

Canesqui, A. M. (2009). Pesquisas qualitativas em nutrição e alimentação. Revista de Nutrição, 22(1), 125-139. https://doi.org/10.1590/S141552732009000100012

Castro, F. M. de. (2018). O alimento "bom, limpo e justo": saúde no discurso do movimento Slow Food no Brasil [Fundação Oswaldo Cruz]. https://www.arca.fiocruz.br/handle/icict/29260

Coca, E. L. de F. (2016). 20 Anos Da Proposta De Soberania Alimentar: Construindo Um Regime Alimentar Alternativo/20 years of the food sovereignty proposal: building an alternative food regime/20 años de la propuesta de la soberanía alimentaria: la construcción de un régimen alime. REVISTA NERA, O(32), 14-33. https://doi.org/10.47946/RNERA.V0I32.4789

Coelho, F. C., Coelho, E. M., \& Egerer, M. (2018). Local food: benefits and failings due to modern agriculture. Scientia Agricola, 75(1), 84-94. https://doi.org/10.1590/1678-992X-2015-0439

Conceição, A. L. (2011). A expansão do agronegócio no campo de Sergipe. Revista GeoNordeste Em Novo Endereço: Www. ..., 2, 1-16. http://200.17.141.110/pos/geografia/geonordeste/index.php/GeoNordeste/article/view/223

Conceição, A. L. (2007). Jovens Andarilhos no curto ciclo do capital. OKARA: Geografia Em Debate, 1(1), 77-100.

CONSEA. (2015). IV Conferência de Segurança Alimentar e Nutricional-Relatório Final.

Dutra, R. C. de A. (2015). Consumo alimentar infantil: quando a criança é convertida em sujeito. Sociedade e Estado, 30(2), 451-469. https://doi.org/10.1590/S0102-699220150002000009

Esteve, E. V. (2017). O négocio da comida. Expressão Popular.

Fischler, C. (1993). L'Homnivore: le goût, la cuisine et le corps. Odile Jacob. 
Garcia, L. J., Teixeira, J. M., Merino, E. A. D., \& Gontijo, L. A. (2011). Gestão de Marca: Influências da hierarquia e arquitetura no posicionamento empresarial. Projetica, 2(2), 05-15. https://doi.org/10.5433/2236-2207.2011V2N2P05

Gudynas, E. (2019). Direitos da Natureza: Ética biocêntrica e políticas ambientais (Elefante (Ed.)).

Hernández, J. C. (2005). Patrimônio e globalização: o caso das culturas alimentares. In A. M. Canesqui \& R. W. D. Garcia (Eds.), Antropologia e nutrição: um diálogo possível (Fiocruz, p. 304).

IDEC. (2020). Desertos alimentares In Folder (p. 2).

Jesus, G. S. de, Costa, J. E. da, \& Silva, A. L. da. (2020). Resistência e contradições em assentamentos rurais no estado de Sergipe: O caso da produção da cana-de-açúcar em Japaratuba e do milho em Monte Alegre de Sergipe / Resistance and contradictions in rural settlements in the state of Sergipe: The case of sugarcane production in Japaratuba and corn in Monte Alegre de Sergipe. Brazilian Journal of Development, 6(1), 2649-2666. https://doi.org/10.34117/BJDV6N1-192

Junior, N. N. G., \& Borges, B. L. (2019). O varejo moderno de alimentos: modernidade e insegurança alimentar e nutricional. Retratos de Assentamentos, 22(1), 11-31. https://doi.org/10.25059/2527-2594/retratosdeassentamentos/2019.v22i1.339

Khoury, C. K., Bjorkman, A. D., Dempewolf, H., Ramirez-Villegas, J., Guarino, L., Jarvis, A., Rieseberg, L. H., \& Struik, P. C. (2014). Increasing homogeneity in global food supplies and the implications for food security. PNAS, 111(11), 4001-4006. https://doi.org/10.1073/pnas.1313490111

Lanes, D. V. C., Santos, M. E. T. dos, Silva, E. F. de S. J., Lanes, K. G., Puntell, R. L., \& Folmer, V. (2012). Estratégias Lúdicas Para a Construção De Hábitos Alimentares Saudáveis Na Educação Infantil. Revista Ciencias \& Ideias, 4(1), 12.

Louzada, M. L. da C., Martins, A. P. B., Canella, D. S., Baraldi, L. G., Levy, R. B., Claro, R. M., Moubarac, J.-C., Cannon, G., \& Monteiro, C. A. (2015). Impact of ultra-processed foods on micronutrient content in the Brazilian diet. Revista de Saúde Pública, 49, 45. https://doi.org/10.1590/S00348910.2015049006211

Lovadini, M. (2017). Indústrias Em Pequenas Cidades: Os Circuitos Espaciais Da Produção E Os Círculos De Cooperação: O Caso Da Aglomeração Urbana De Piracicaba-Sp. Estudos Geográficos: Revista Eletrônica de Geografia, 15(0), 101-120. https://doi.org/10.5016/estgeo.v15iespecial.12783

Luz, V. G., Zangirolani, L. T. O., Vilela, R. A. de G., \& Corrêa Filho, H. R. (2014). Consumo alimentar e condições de trabalho no corte manual de cana de açúcar no estado de São Paulo ${ }^{1}$. Saúde e Sociedade, 23(4), 1316-1328. https://doi.org/10.1590/S0104-12902014000400016

Machado, P. P., Oliveira, N. R. F. de, \& Mendes, Á. N. (2016). O indigesto sistema do alimento mercadoria. Saúde e Sociedade, $25(2)$, 505-515. https://doi.org/10.1590/S0104-12902016151741

Maluf, R. S., \& Reis, M. C. dos. (2013). Conceitos e Princípios de Segurança Alimentar e Nutricional. In C. Rocha, L. Burlandy, \& R. Magalhães (Eds.), Segurança Alimentar e Nutricional: Perspectivas, aprenzidados e desafios para as políticas públicas. 15-42. Fiocruz.

Matthes, D., \& Checcucci, M. (2019). Cuca (Kuchen): a Transformação Do Alimento Tradicional Em Ultraprocessado E As Implicações No Desenvolvimento Regional. IX Seminário Internacional Sobre Desenvolvimento Regional, 2004, 1-16.

Monteiro, C A, Cannon, G., \& Levy, R. B. (2016). A estrela brilha. World Nutrition Janeiro-Março, 7(3), 28-40.

Monteiro, Carlos A., \& Cannon, G. (2012). The Impact of Transnational "Big Food" Companies on the South: A View from Brazil. PLOS Medicine, 9(7), e1001252. https://doi.org/10.1371/JOURNAL.PMED.1001252

Nebin, N. de E. e B. da N. da U. F. do R. de J. (2019). Software Recordatório Brasil Nutri.

Oliveira, A. C. da S., \& Souza, L. M. B. de. (2017). Avaliação Da Frequência Do Consumo De Alimentos Ultraprocessados De Crianças Menores De 10 Anos. South American Development Society Journal, 2(6), 143-154. http://www.sadsj.org/index.php/revista/article/view/56

Oliveira, E. R. S. dos S., \& Costa, J. E. da. (2013). A dinâmica do agronegócio em Lagarto/SE: limites, impasses e alcances. GeoNordeste, 3.

OPAS, O. P.-A. da S., \& OMS, O. M. da S. (2017). Sistemas alimentares e nutrição: a experiência brasileira para enfrentar todas as formas de má nutrição. https://www.cfn.org.br/wp-content/uploads/2017/09/oms.pdf

OXFAM. (2013). Por Trás Das Marcas. 56. http://www.behindthebrands.org/ /media/Download-files/Relatorio_PorTrasDasMarcas.ashx

Paula, N. de. (2017). Evolução do Sistema Agroalimentar Mundial. SRV.

Pinto, I. F., Campos, C. J. G., \& Siqueira, C. (2019). Investigação qualitativa: perspectiva geral e importância para as ciências da nutrição. ACTA Portuguesa de Nutrição, 14, 30-34. https://doi.org/10.21011/apn.2018.1406

Pollan, M. (2006). O dilema do onívoro. Intrínseca.

Porto, M. F. (2007). Agrotóxicos, saúde coletiva e insustentabilidade: uma visão crítica da ecologia política. Ciência \& Saúde Coletiva, 12(1), 17-20. https://doi.org/10.1590/S1413-81232007000100004

Sampaio, I. S. V., Cavalcante, A. P. P., Craveiro, P. S. U., Monteiro, M. C. S., Miranda, P. de, Máximo, T. M., Sombra, Á. S. A., Lerquin, C. C. F., \& Maia, M. S. G. (2016). Publicidade Infantil em tempos de convergência - Relatório Final.

Santana, G. S., Ribeiro, R. de C. L., Santos, A. C. dos, Silva, D. G. da, Fagundes, A. A., \& Voci, S. M. (2018). I Relatório de Indicadores de Segurança Alimentar e Nutricional do Estado de Sergipe. 
Research, Society and Development, v. 10, n. 14, e64101421596, 2021

(CC BY 4.0) | ISSN 2525-3409 | DOI: http://dx.doi.org/10.33448/rsd-v10i14.21596

Scrinis, G. (2015). Reformulation, fortification and functionalization: Big Food corporations' nutritional engineering and marketing strategies. Http://Dx.Doi.Org/10.1080/03066150.2015.1101455, 43(1), 17-37. https://doi.org/10.1080/03066150.2015.1101455

Silva, N. B., Moura, V. M. das C., Ibiapina, D. F. N., \& Bezerra, K. C. B. (2019). Aditivos químicos em alimentos ultraprocessados e os riscos à saúde infantil. Revista Eletrônica Acervo Saúde, 21, e542-e542. https://doi.org/10.25248/REAS.E542.2019

Silveira, M. L., Martins, M. C., Oliveira, E. K. F., Joventino, E. S., \& Ximenes, L. B. (2014). Revista da Rede de Enfermagem do Nordeste Universidade Federal do Ceará Brasil. Revista Da Rede de Enfermagem Do Nordeste, 15(1), 37-44. https://doi.org/10.15253/2175-6783.2014000100006

Souza, T. R., \& Carvalho, C. M. P. de. (2019). Refletindo sobre lobbies alimentares e outras ações corporativas. Revista Ingesta, 1(2), 119-120. https://doi.org/10.11606/ISSN.2596-3147.V1I2P119-120

Souza, T. T. (2017). Globalização por Caminhões. RELACult - Revista Latino-Americana de Estudos Em Cultura e Sociedade, 3(3). https://doi.org/10.23899/relacult.v3i3.536

Toebe, D., Sand, I. C. P. Van der, Cabral, F. B., Hildebrandt, L. M., \& Begnini, D. (2018). Práticas de autoatenção relativas à alimentação de crianças do meio rural. Revista Gaúcha de Enfermagem, 38(3). https://doi.org/10.1590/1983-1447.2017.03.64507

Unicef. (2019). Situação Mundial da Infância 2019: Crianças, alimentação e nutrição - Crescendo saudável em um mundo em transformação - América Latina e Caribe.

Vicentini, M. S. (2015). Alimentos industrializados: abordagem da indústria, consumidores e governo. Segurança Alimentar e Nutricional, 22(1), 671-682. https://doi.org/10.20396/SAN.V22I1.8641609

Zimmermann, C. L. (2009). Monocultura E Transgenia: Impactos Ambientais E Insegurança Alimentar. Veredas Do Direito: Direito Ambiental e Desenvolvimento Sustentável, 6(12). https://doi.org/10.18623/RVD.V6I12.21 